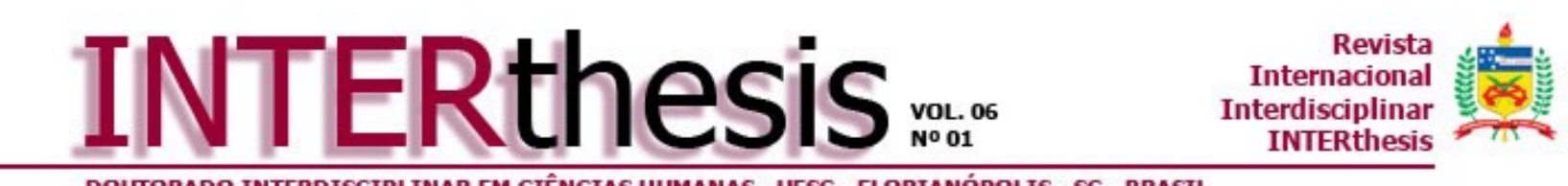

DOUTORADO INTERDISCIPLINAR EM CIÊNCIAS HUMANAS - UFSC - FLORIANÓPOLIS - SC - BRASIL

\title{
MULHERES E DIREITOS HUMANOS: DESFAZENDO IMAGENS, (RE)CONSTRUINDO IDENTIDADES
}

\section{WOMEN AND HUMAN RIGHTS: UNDOING IMAGES, (RE) CONSTRUCTING IDENTITIES}

\section{MUJERES $Y$ DERECHOS HUMANOS: DESHACIENDO IMÁGENES, (RE)CONSTRUYENDO IDENTIDADES}

\section{Nilda Stecanela ${ }^{1}$ Pedro Moura Ferreira ${ }^{2}$}

\section{RESUMO:}

Situado no contexto dos estudos de gênero e violência, este artigo interpreta atos de violência praticados contra a mulher, nomeadamente aqueles em que a vítima procura os setores de apoio. É parte de uma pesquisa em desenvolvimento no Sul do Brasil. Problematiza a necessidade de "desconstruir velhas imagens" para dar lugar a "novas identidades" como forma de auxiliar a mulher a sair da condição de vítima, para protagonizar sua própria vida, como autora de suas escolhas e de sua história. Relaciona a urgência na revisão dos processos de socialização para imprimir, nas práticas cotidianas, com homens e mulheres, outro jeito de perceber, conceber e viver a condição de mulher e de homem na contemporaneidade. Parte do princípio de que não basta garantir direitos à mulher e/ou punir agressores. Considera urgente o testemunho de uma nova cultura sobre as questões de gênero. O problema evidenciado, nos primeiros contatos com o campo, sinaliza que o combate à violência de gênero tem íntima relação com as representações que as mulheres têm sobre a violência doméstica, pois a maior parte delas somente reconhece as violências físicas, ignorando outras formas. Genericamente, consideram naturais as desigualdades de gênero e acreditam ocupar lugar subalterno em relação aos homens. A violência de gênero é uma construção social, que fortalece a dominação masculina e oprime as mulheres. O desafio que se coloca é, pois, transformar a violência contra a mulher, de um problema privado, num problema público, ou seja, como um problema de direitos humanos e de igualdade de gênero.

Palavras-chave: Identidades de gênero; Direitos humanos; Violência contra a mulher.

\section{ABSTRACT:}

Located in the context of studies on gender and violence, this paper interprets cases of violence against women, namely those in which the victim seeks for support services. It is part of a research being carried out in the southern region of Brazil, and debates the need

\footnotetext{
${ }^{1}$ Doutora em Educação. Docente no Programa de Pós-Graduação em Educação da Universidade de Caxias do Sul (UCS). Professora na Rede Municipal de Ensino de Caxias do Sul. Coordenadora do Observatório de Educação Infâncias e Juventudes da UCS. E-mail: nildastecanela@terra.com.br

${ }^{2}$ Doutor em Sociologia. Investigador no Instituto de Ciências Sociais da Universidade de Lisboa/Portugal. Email: pmferreira@ics.ul.pt
} 
to "deconstruct old images" in order to give place to "new identities" as a form of helping women to move from a victim's position towards playing the leading role of their own lives, in charge of their own choices and writing their own stories. This paper relates the urgency to revise socializing processes that will inculcate on everyday practices - of both men and women - another way of perceiving, conceiving and living their conditions as men and women in contemporaneity. It starts from the principle that it is not enough to assure rights and punish the aggressors. What has become evident in our first contacts with the research field points at the fight against gender violence being closely related to the representations that women have about domestic violence, since most of them only acknowledge physical violence, ignoring the other forms of violence. Generically, they consider gender differences as something natural and believe they occupy an inferior position in relation to men. Gender violence is a social construction that strengthens male domination and oppresses women. The challenge, thus, is to transform violence against women from a private into a public problem; that is, into an issue of human rights and gender equality.

Key-words: Gender identities; Human rights; Violence against women.

\section{RESUMEN:}

Situado en el contexto de los estudios de género y violencia, este artículo interpreta casos de violencia practicada contra la mujer, específicamente aquellos en los que la víctima busca los sectores de apoyo. Forma parte de una investigación en desarrollo en la región sur de Brasil. Problematiza la necesidad de "des-construir viejas imágenes" para dar lugar a las "nuevas identidades" como forma de auxiliar a la mujer a salir de la condición de víctima, para protagonizar su propia vida, como autora de sus elecciones y de su historia. Relaciona la urgencia en la revisión de los procesos de socialización para imprimir en las prácticas cotidianas, con hombres y mujeres, otra manera de percibir, concebir y vivir la condición de mujer y de hombre en la contemporaneidad. Parte del principio que no es suficiente garantizar derechos y punir agresores. Considera urgente el testimonio de una nueva cultura sobre las cuestiones de género. El problema evidenciado en los primeros contactos con el campo señala que el combate a la violencia de género tiene íntima relación con las representaciones que las mujeres tienen sobre la violencia doméstica, pues la mayor parte de ellas solamente reconoce las violencias físicas, ignorando las otras formas. Genéricamente, consideran naturales las desigualdades de género y creen ocupar un lugar subalterno en relación a los hombres. La violencia de género es una construcción coloca social que fortalece la dominación masculina y oprime a las mujeres. El desafío que esta puesto es transformar la violencia contra la mujer, de un problema privado, en un problema público, o sea, como un problema de derechos humanos y de igualdad de género.

Palabras-clave: Identidades de género; Derechos humanos; Violencia contra la mujer. 


\section{INTRODUÇÃO}

As reflexões que apresentamos neste texto compõem uma primeira aproximação à análise dos dados empíricos resultantes de um estudo exploratório, realizado no contexto do projeto de pesquisa "Mulheres e direitos humanos: desfazendo imagens, reconstruindo identidades", financiado pela Secretaria Especial de Políticas para as Mulheres (SPM), em parceria com a Prefeitura Municipal de Caxias do Sul (através da Coordenadoria da Mulher) e a Universidade de Caxias do Sul.

O banco de dados do estudo é composto por entrevistas realizadas com 27 mulheres, vítimas de violência de gênero e por 31 agentes públicos que, direta ou indiretamente, compõem a Rede de Proteção à Mulher do Município de Caxias do Sul.

A pesquisa baseia-se numa abordagem de ordem teórica e metodológica, focalizada nas construções socioculturais relativas às questões de gênero, numa perspectiva de desfazer imagens cristalizadas e de reconstruir posturas e leituras sobre 0 tema. Desenvolve um olhar especial sobre as representações que a mulher vítima tem sobre a violência de gênero.

Numa análise transversal da sociografia da amostra que compõe o estudo e das narrativas produzidas nas entrevistas com as mulheres, apresentamos, a seguir, algumas categorias reveladoras de algumas das tendências que nos desafiam ao aprofundamento.

\section{AS MÚLTIPLAS VIOLÊNCIAS NARRADAS PELAS VÍTIMAS}

Entre os motivos que levam a mulher, vítima de violência, a procurar ajuda, as agressões físicas, sem dúvida, estão no topo das denúncias e no limiar da suportabilidade da situação conjugal. Esse tipo de violência parece ser o grande desencadeador do processo que conduz a mulher à "vitimização afirmativa", da qual nos fala Soares (1999), como forma de produzir um discurso sobre si mesma, assumindo, publicamente, para si e para testemunhas, a emblemática expressão: "Eu sou uma mulher que apanha." Entretanto, é preciso dar atenção aos aspectos que circundam e antecedem esse movimento e que, muitas vezes, narram justificativas sobre as construções culturais que envolvem as questões de gênero, bem como às representações que essas mulheres construíram sobre a violência sofrida em seu processo de socialização. 
$\mathrm{Na}$ ótica de Soares (2005), a violência física ou as ameaças verbais que levam a mulher a pedir ajuda, podem ser apenas a ponta do iceberg da situação de violência à que as mulheres encontram-se submetidas.

Os testemunhos das entrevistadas indicam que a violência emocional sempre aparece associada à violência física, mas não integra os principais motivos para o pedido de socorro, sendo apenas coadjuvante no processo de denúncia ou busca por orientação quanto aos seus direitos. Uma das mulheres entrevistadas, no momento em que fazia a denúncia, disse: "Foi só ameaça verbal." O "só” não vem sozinho nessa expressão, mas está carregado das representações que essa mulher tem sobre a violência de que é vítima, quase justificando que ela própria não teria motivos consistentes para a efetivação da denúncia. Outra vítima diz: "É sempre aquela coisa: começa com um puxão de cabelo hoje, um tapa amanhã, e as mulheres pensam que é só uma demonstração de ciúmes e depois tenta continuar porque acha que ele vai mudar e assim vai indo. Eu até me perguntei: o que eu estava fazendo de errado?

Podemos interpretar essas posturas a partir do conceito de representação desenvolvido pela História Cultural, enquanto uma disciplina que estuda os processos com os quais os sujeitos, através de suas narrativas, constroem sentidos para as coisas (CHARTIER, 1988). Estão em jogo nesse processo os aspectos culturais que envolvem o lugar que essas mulheres ocupam na relação que estabelecem com os companheiros. $A$ cultura, nesse caso, envolve um conjunto de significados que elas constroem e partilham em seus processos de socialização, como forma de explicar as vivências com a violência de que são vítimas. Recorrendo a Pesavento (2008, p.15), podemos entender a cultura como "uma forma de expressão e de tradução da realidade que se faz de forma simbólica, ou seja, admite-se que os sentidos conferidos às palavras, às coisas, às ações e aos atores sociais se apresentam de forma cifrada". Nesse sentido, as palavras das mulheres sobre a situação que vivem com a violência, nos permitem ler as representações que constroem sobre o vivido. Essa autora, afirma que "as representações construídas sobre o mundo não só se colocam no lugar deste mundo, como fazem com que os homens percebam a realidade e pautem a sua existência” (p. 39). Para ela, as representações atuam como "matrizes geradoras de condutas e práticas sociais, dotadas de força integradora e coesiva, bem como explicativa do real” (PESAVENTO, 2008, p.39). 
Como portadoras do simbólico, as representações, acabam dizendo mais do que aquilo que enunciam, uma vez que carregam sentidos ocultos, construídos social e historicamente, os quais são internalizados no inconsciente coletivo e, na maior parte das vezes, se apresentam como naturais, como é o caso das violências encobertas no corpo da mulher.

Assim, sob a categorização "violência emocional", é possível localizar algumas recorrências nas expressões empregadas pelas depoentes. Entre elas, a ameaça e a agressão verbal aparecem com maior frequência e com derivações que apontam para atitudes de humilhação, coação e chantagem, as quais produzem sentimentos de menos valia e impotência para a reversão do quadro. A "violência psicológica", decorrente dos comportamentos do agressor, quase não aparece nas narrativas das mulheres vítimas, indicando fortes marcas da "banalização da violência".

Chama a atenção o depoimento de uma das vítimas ao afirmar que, entre as razões que levam um homem a agredir sua companheira, está a culpa que a própria mulher se impõe, pois ela crê que "se apanhou é porque fez alguma coisa de errado", justificando que "para a coisa chegar neste ponto, quando um casal vive junto, só pode que ela tenha feito alguma coisa de errado". Esse depoimento retrata as construções culturais envolvidas no fenômeno da violência, entre as quais está o reforço da naturalização da dominação masculina por parte de muitas mulheres. Isso decorre também de uma construção histórica em que, "durante muitos séculos, em nossa sociedade, o direito de um homem castigar sua mulher estava assegurado pela lei e legitimado culturalmente". (SOARES, 1999, p. 25).

Embora as mulheres contemporâneas mostrem-se mais encorajadas em denunciar as violências que sofrem, numa espécie de "saída do armário" (SOARES, 1999, p. 15), percebe-se que o deslocamento e a redefinição da culpa e da vitimização, muito lentamente, vão assumindo contornos em direção à quebra do silêncio e à publicização do segredo.

A partir do momento em que essas vítimas procuram apoio nas instituições que a Rede de Proteção à Mulher de Caxias do Sul disponibiliza para sua orientação, atendimento e encaminhamentos, também contribuem para a constituição de um processo educativo que, certamente, afetará os processos de socialização de seus filhos e, quiçá, do próprio agressor, com a produção de um discurso em torno da experiência da 
vitimização. As vítimas descobrem os caminhos tortuosos e dolorosos em direção ao rompimento do círculo da violência. Elas passam a usufruir o direito a um atendimento especial nas Delegacias de Mulheres e começam a conhecer outras instâncias das políticas públicas, voltadas à sua proteção, como é o caso do Centro de Referência da Mulher e da Rede de Proteção à Mulher, além, sem dúvida, dos benefícios decorrentes da Lei Maria da Penha.

A partir da vitimização afirmativa, assistimos à construção de outras representações, pois, como afirma Chartier (1991), elas configuram resultado dos processos nos quais os indivíduos se envolvem em seus percursos de vida. Através da sua interiorização, apropriação ou interpretação, enquanto acontecimentos significativos, esses processos reelaborados, ganham novos sentidos, ou seja, novas representações para cada sujeito que pertence a uma determinada categoria, grupo ou classe social.

Com isso, algumas narrativas, ainda tímidas, começam a ganhar contornos diferenciados, tirando-as da passividade e desafiando-as a procurar ajuda como exemplifica o depoimento de uma vítima de 45 anos, recicladora de resíduos sólidos, em seu segundo relacionamento, a qual denunciou o companheiro pela primeira vez após três semanas sofrendo agressões: "Vou dizer uma coisa pra ti, se tu baixar a cabeça na primeira vez, daí vai te bater sempre, então agressão maior é porque a gente aceita. Porque agride uma vez, agride sempre."

O limite externo às agressões dado pela procura da polícia é apenas um passo que, certamente, se ancora nos limites internos que essa mulher constrói para dar um basta à violência que sofre. Porém, sem ajuda, ela não consegue sair do círculo da violência.

Na sala de espera da Delegacia da Mulher ou do Centro de Referência, durante o trabalho de campo, foi comum observar mulheres narrando suas experiências de vitimização, descrevendo em detalhes o sofrimento vivido na intimidade, para outras mulheres que também aguardavam atendimento e orientação ou para funcionários do serviço. Segundo uma recepcionista, "as vítimas querem ser escutadas, elas precisam falar para alguém o que elas sofrem e, ao falar, elas vão construindo justificativas internas para dizer não à situação". Com isso, rompe-se com a perpetuação do silêncio, e o sofrimento deixa de pertencer ao domínio das trajetórias individuais, pois passa a ser 
generalizado como uma forma de violência comum, de uma vitimização que atinge mulheres coletivamente. (SOARES, 1999, p. 29).

Como já dito anteriormente, a violência física, tomada no seu sentido estrito, ou seja, como uma violência mensurável e isenta de contestações, em geral praticada no interior da casa, lugar que deveria ser considerado abrigo e proteção, é a propulsora da denúncia e do primeiro passo em direção à "vitimização afirmativa". "[Ele] me ameaçou com arma, ele me bateu com ferro, tirou meu braço do lugar. Desta vez ele me ameaçou com faca, daí eu corri e me protegi." Não podemos deixar de sublinhar que essa violência, embora com as marcas visíveis deixadas no corpo da mulher, com o uso concreto da força e as decorrências do ato brutal, em muitos casos, aparece cotidianamente disfarçada, sendo encoberta de forma intencional ou não pelas próprias vítimas ou pelos agentes de atendimento.

Uma vítima narrou que sofria vários tipos de violência há dez anos, nomeando-a violência física e psicológica. Segundo essa mulher de 32 anos, "os cortes na cabeça, o roxo das agressões somem, mas o psicológico..." Muito nervosa, ela afirma que demorou em denunciar, pois "tinha medo... medo... medo..." Esse processo caracteriza "vítimas duplamente feridas: pelo ataque do outro e por aquele que impõem a si mesmas, na tentativa de negar a realidade que é sua”. (OLIVEIRA, 1999, p. 1).

Não se pode negligenciar que a violência física produz outros tipos de violências, como é o caso da violência psicológica, em geral, encoberta pelo rótulo da agressão verbal e das ameaças e que, felizmente, são violências enquadradas como crime e, portanto, passíveis de registro. (CONRADO, 2001). De ameaçadas, as mulheres passam a ameaçar, com o poder que têm à mão, ou seja, o direito à denúncia pelas múltiplas violências que sofrem: sexual, física, patrimonial, verbal, psicológica e emocional. $\mathrm{O}$ recurso à denúncia nas Delegacias da Mulher ou a procura por ajuda em alguma instituição de apoio, leva para além da porta de casa a intimidade vivida pelo casal, provocando constrangimentos em ambos, mas com a esperança que "dar um susto nele" possa minimizar ou cessar as agressões.

Nem sempre essa mulher deseja a separação, dizendo-se afetivamente ligada ao agressor e preocupada com o sustento dos filhos e a manutenção do pequeno patrimônio que construíram juntos. Ao mesmo tempo em que assume não querer mais a repetição da situação, ela recua e aceita o companheiro de volta, reiniciando o ciclo: "Denunciei depois 
de apanhar. Eles vieram e levaram ele, mas quando ele voltou, continuou sendo violento." Muitas sonham em conseguir reverter à situação e dizem que não querem mais ficar com o agressor porque já deram uma chance e nada adiantou: "ele voltou a agredir".

Uma das formas de impedir a construção da autonomia da mulher e de perpetuar a dominação é encoberta pelo sentimento de ciúmes do agressor. Com essa justificativa, eles não permitem que as companheiras trabalhem ou estudem, cerceando as relações sociais dessas mulheres, controlando seus movimentos, impedindo que elas vislumbrem outros cenários para sua vida. "Eu estava trabalhando, parei porque ele não deixou mais." Com o afastamento do agressor, ressurge uma possibilidade de reconstrução da própria vida e de reencontrar o prazer de viver. "Adoro trabalhar, sempre trabalhei. E agora que vou ficar sozinha, vou fazer um curso, estudar."

Segundo Almeida (2007, p. 25), as violências narradas por essas vítimas e que deixam "inúmeras, diversificadas e profundas marcas em mulheres, em escala global, ainda não foi nominada apropriadamente". Para a autora, trata-se de uma violência "maldita" e de uma violência "mal-dita" [sic]. O primeiro enfoque é atribuído a "todas/os que a experimentaram e para todas/os que tentaram enfrentá-la e mediá-la". O segundo enfoque é referido "para todas/os que tentam estudá-la". Com essa diferenciação, a autora alerta que distintas expressões são utilizadas com sentido equivalente, a citar: violência contra a mulher, violência doméstica, violência intrafamiliar e violência de gênero. Diz ainda que os diversos significados dessas categorias encerram implicações teóricas e práticas. De forma didática, a autora apresenta as especificidades de cada denominação, sugerindo algumas diferenciações:

Violência contra a mulher enfatiza o alvo contra o qual a violência é dirigida. É uma violência em que não há um sujeito, só objeto; acentua o lugar da vítima, além de sugerir a unilateralidade do ato. Não se inscreve, portanto, em um contexto racional.

Violência doméstica é uma noção espacializada, que designa o que é próprio à esfera privada - dimensão da vida social que vem sendo historicamente contraposta ao público, ao político. Enfatiza, portanto, uma esfera da vida independentemente do sujeito, do objeto ou do vetor da ação.

Violência intrafamiliar aproxima-se bastante da categoria anterior, ressaltando, entretanto, mais do que o espaço, a produção e a reprodução endógenas da violência. É uma modalidade de violência que se processa no interior da família. 
Violência de gênero designa a produção da violência em um contexto de relações produzidas socialmente. Portanto, o seu espaço de produção é societal, e o seu caráter é relacional. (ALMEIDA, 2007, p. 23-24).

Essa autora produz argumentos a favor e contra cada uma das categorias de violência empregadas no cotidiano, mas se posiciona pelo uso da violência de gênero, pois seria o único qualificativo da violência que ultrapassa o caráter descritivo, constituindo-se em categoria analítica e histórica ao mesmo tempo, sendo facilmente assimilável no meio acadêmico. Marcada por uma incompletude, dado seu caráter abrangente, o seu emprego poderia levar ao risco de transbordamento, porém não da limitação. Suas potencialidades estariam sinalizadas pela abordagem da violência no quadro das desigualdades de gênero. (ALMEIDA, 2007, p. 26-27).

\section{A INTERVENÇÃO NO AGRESSOR: INTERMEDIAÇÃO E REPRESSÃO}

Analisando os depoimentos de mulheres, vítimas de agressões, que foram entrevistadas no espaço da Delegacia Especial de Mulheres, pode-se antecipar que a reivindicação de segurança mostra que a mulher, que vivencia uma experiência de agressão, vivencia, de igual modo, sentimentos de medo, de insegurança e de ameaça à sua vida.

Percebe-se que a necessidade de defesa está presente, também, em outras categorias. Em primeiro lugar, pelas medidas repressivas que são defendidas. Praticamente preconiza-se a prisão (ou mais). A ideia de uma justiça retaliativa também está presente (fazer o mesmo com o agressor). Em segundo lugar, a ideia de recuperação e tratamento está praticamente ausente, como se a ideia de uma segunda oportunidade estivesse morta. As mulheres querem proteção, defesa da sua integridade, e isso só se torna possível com o afastamento do agressor, se possível encerrado na prisão. O destaque da repressão dá ideia da dimensão do sofrimento contido na experiência de vitimação.

Há ainda dois pontos a sublinhar: se a questão da segurança é a mais importante, outras existem que não devem ser descuradas. Por exemplo, o apoio legal à vítima no processo de reconstituição de sua vida (defesa dos seus direitos), realça o aspecto de que a proteção da vítima não se esgota nas questões da segurança, mas deve ser 
estendido à reconstituição das suas vidas. Por último, a questão da inação do sistema policial. Algumas mulheres criticam a demora da resposta e o tipo de atenção que é dado ao problema da violência. Há uma complacência demasiada ou um menosprezo a esse tipo de intervenção, por se considerar socialmente que é do domínio privado e, por conseguinte, fora da ação das forças policiais.

Esses aspectos sugerem algumas indagações: Por que razão o sistema tem dificuldade em garantir segurança à vítima? Como responde o sistema à questão do agressor? Que apoio têm as mulheres na reconstituição de sua vida? Como se dissuade o agressor de recorrer futuramente à violência contra a mulher? Que sensibilidade há nas forças policiais para a questão da violência contra a mulher?

As vítimas reclamam uma intervenção por parte das autoridades. A atitude básica é de reivindicar uma proteção, uma garantia à sua segurança e integridade, por vezes até à dos filhos e familiares. O medo da retaliação, da violência repetida, é uma experiência comum de sofrimento. Apesar disso, também em razão da experiência de vitimação pela qual estão passando, a intervenção que se preconiza não é a mesma. É possível distinguir dois tipos extremos de intervenção: de um lado, situa-se o que poderia ser visto como uma função de intermediação; do outro, uma função repressiva. Essas alternativas de intervenção da polícia em relação ao agressor emergem das narrativas das mulheres e podem ser categorizadas como formas de proporcionar segurança à vítima; garantir ação preventiva; contribuir com o empoderamento e a defesa dos interesses da vítima; produzir uma medida de tratamento obrigatório; e efetivar uma ação repressiva contra o agressor. Em alguns casos, aparecem como uma crítica à inação policial e à impotência do sistema ou como falta de opinião formada sobre o assunto, com fortes marcas do desespero e da descrença de que a situação poderá mudar.

Por função de intermediação entende-se uma intervenção que tem por objetivo chamar o agressor à responsabilidade dos seus atos e das consequências que deles podem resultar. Não se apela diretamente a uma função repressiva. É uma intervenção que visa a colocar pressão externa sobre o agressor, tornar público o seu comportamento, e, talvez, o mais importante, oficializar a agressão, permitindo reforçar a capacidade negocial da vítima e protegê-la de futuras agressões. Como diz uma mulher: "Que conversem com ele para parar as ameaças." Algumas vezes o recurso de ir à delegacia é usado como forma de pressionar uma divisão justa e equitativa dos bens. Não raramente, 
os bens estão em nome do marido, que dificulta a divisão, mesmo quando a separação conjugal está de fato consumada. Mas também, nesse caso, o que se procura é uma função de intermediação, que permita alterar uma situação, que se acredita poder ser resolvida sem recorrer a meios mais repressivos ou judiciais. Como se vê, o tipo de intervenção requerido pela vítima está diretamente relacionado com a natureza da vitimação, com a atitude da vítima diante do vínculo conjugal e com a crença acerca da possibilidade de o agressor alterar o seu comportamento.

Do lado do pólo repressivo, as medidas preconizadas também não são uniformes. Há nos testemunhos das mulheres duas ideias: por um lado, a da segurança, que também está presente na função de intermediação, mas que se revela agora mais acutilante na medida em que a experiência do medo é mais intensamente experimentada. Por outro, a ideia de justiça, que apela a uma reparação do sofrimento que the foi causado. É evidente a existência de um elo entre essa necessidade de justiça e a experiência de vitimação sofrida. Não custa admitir que a expressão dessa necessidade é tanto mais intensa quanto são a impotência e a revolta em face da arbitrariedade da violência. A reivindicação básica é de que a polícia deveria auxiliar na proteção da vítima contra o agressor. O que se pede não é uma função de intermediação, mas de proteção. O medo da ameaça está presente. Em alguns casos, talvez menos problemáticos do ponto de vista da violência, pede-se que o agressor seja afastado do lar, ou seja, obrigado a submeter-se a tratamento médico. Para essas mulheres, o problema nem sempre é conseguir uma separação definitiva, mas romper com uma situação, as quais consideram opressiva e que se prolonga através de chantagens afetivas, designadamente usando os filhos, e de ameaças veladas ou explícitas, quando não se valem do recurso à agressão física.

A reivindicação de uma medida de afastamento do lar pode ser conseguida através de meios repressivos. Para uma parte das vítimas, pede-se a prisão para o agressor. Não se trata apenas de uma forma de se obter a segurança delas. É mais do que isso: reivindica-se justiça, a reparação de um dano. Algumas pedem uma justiça mais retaliativa, sugerindo que "a polícia deveria fazer com o agressor o mesmo que ele faz com a gente" e usar também a repressão física. "No meu ver era de pegar e dar um 'laço' e descascar na surra, porque a partir do momento que tu cria os filhos dele, e ele te espanca na frente dos filhos, ele só merece isso mesmo." Outros testemunhos apontam à 
mesma direção: "Mas a polícia tinha que tirar o agressor, tem de botar os vagabundos trabalhar de dia até noite, fazer sentir na pele, pôr na cadeia não adianta!" Mas nem todas as falas se alinham nesse diapasão. Há quem não vá tão longe, mas não deixa de expressar o mesmo sentimento de revolta e de injustiça: "Acho que devia ter punição... eu não sei... uma multa, alguma coisa para ele pagar, não sei..." Assim a reivindicação de justiça sobrepõe-se, nas falas dessas vítimas, à questão da segurança.

A reivindicação da ideia de justiça poderia fazer supor, mais do que no caso da função de intermediação, uma consciência mais intensa de direitos, mas é muito duvidoso que seja disso que se trata. Não se depreende das falas das vítimas uma referência à criminalização da violência nem aos direitos que assistem as mulheres. O recurso à delegacia é um pedido de auxílio, não um direito a que o cidadão pode recorrer. É o medo que move as vítimas e não a liberdade de defender os seus direitos.

É evidente que, quer os capitais escolares que, de uma forma geral, são baixos no universo inquirido, quer o peso de uma tradição que, no mínimo, tende a ser complacente com a violência doméstica, vista ainda como um problema de ordem privada, inibem o desenvolvimento de uma consciência de direitos e a criminalização da violência conjugal. Apesar dessas inibições, as mulheres sabem que podem encontrar na lei um auxílio, mesmo quando não sabem muito bem o que decorre da intervenção legal. "Botei na mão da lei, eu só quero continuar vivendo com o meu filho, cuidar da minha vida. Sofro tanto nas mãos dele, e homem na minha vida não quero mais." E também não está muito claro, até que ponto, elas confiam nesse auxílio. "Faz mais de um ano que fiz essas ocorrências e nunca aconteceu nada, só agora veio a carta de intimação, não sei o que vai dar ainda..."

Os queixumes estendem-se à polícia, acusando-a de nada fazer em relação ao agressor. Seja como for, o recurso à delegacia é a última esperança de pôr fim a uma situação de opressão, sobretudo quando a vítima encontra pouco apoio na família e na vizinhança.

O pedido que fazem às autoridades tem por isso pouco a ver com o conhecimento da lei ou a defesa dos direitos. A intervenção a que apelam, seja a de intermediação, seja a repressiva, tem a ver, sobretudo, com a experiência de vitimação. Se a violência se confina ao plano da agressão verbal, normalmente, é reivindicada a função de intermediação. Se, pelo contrário, assume contornos físicos que se repetem e 
reproduzem o ciclo da violência, apela-se claramente, como se viu, à intervenção repressiva e a um sentimento de justiça muito baseado na Lei de Talião, que encontra a sua justificação no sofrimento causado. É porque sofrem que denunciam e exigem proteção e justiça, na proporção direta do seu sofrimento.

\section{A VítIMA E SUAS REPRESENTAÇÕES SOBRE A RESSOCIALIZAÇÃO DO AGRESSOR}

O tipo de violência sofrida e a sua intensidade moldam as representações das vítimas não apenas à forma com que as autoridades lidam com o agressor, mas também em relação às possibilidades de ressocialização do mesmo. A maior parte das mulheres, mesmo quando não explicitam, dá a entender o desejo de se libertarem do vínculo que as liga ao agressor. Esse desejo, entretanto, não estará em todas elas, mas, sobretudo, nas que estão sujeitas a uma violência mais contida e intermitente, mais associada, como já foi referido, a uma intervenção de intermediação. É provável que essas se mostrem mais confiantes na capacidade de regeneração do agressor. Há, com efeito, dois grupos de atitudes: as que dizem acreditar que o agressor poderá deixar de ser violento, e as que afirmam não acreditar que isso possa vir a acontecer. Como sugerido, no primeiro grupo encontram-se as mulheres que sofrem agressões verbais, mas não físicas, e que apelam, sobretudo, a uma intervenção de intermediação. No outro grupo, estão mulheres que sofrem todo tipo de violência e de forma mais repetitiva, que são as que preconizam uma resposta mais repressiva.

Mais interessante do que diferenciar esses dois grupos é atender às razões que apresentam quer para o caso de acreditarem na regeneração do agressor, quer para o caso contrário, ou seja, de descrerem na sua ressocialização. A regeneração do agressor é considerada possível em duas situações, que, aparentemente, não estão articuladas. Uma delas aponta para o tratamento, que está, sobretudo, relacionada com o consumo de drogas. "Sim [acredita que o agressor pode deixar de ser violento], se for tratado, pois ele era calmo e tranquilo. O problema é o crack." Mas se o tratamento pode constituir uma razão para crer na viabilidade da recuperação, não é, contudo, a razão que mais vezes foi citada, na fala das mulheres, que têm nisso uma crença positiva. A razão principal reside no controle do agressor, ou seja, essas mulheres acreditam que os problemas 
desaparecerão, ou pelo menos diminuirão, se o agressor for monitorado de perto pelas forças policiais. "Sim, mediante intervenção policial, se perceber que alguma coisa está sendo feita." Reencontra-se, aqui, a ideia equacionada, relativa à função de intermediação de que a vítima pretende um reforço da sua posição de forma a poder controlar a relação que mantém com o agressor e não às condições de segurança, como acontece com outras mulheres, para uma ruptura definitiva.

Às vezes, a recuperação é vista como dependente da capacidade do agressor de controlar ou ser obrigado a controlar algumas impulsividades. "Sim, que conversem com ele para que deixe de ser ciumento." Também nesse caso, a crença na ressocialização do agressor está dependendo do controle externo do seu comportamento. Se anteriormente dependia do controle médico, agora é visto como decorrente da terapêutica psicológica, que pode, aparentemente, ser substituída por um controle e uma pressão de natureza policial.

As razões que justificam o descrédito da ressocialização são também variadas. Podem ser reunidas em três grupos: o primeiro revela o ceticismo em relação ao tratamento ou por recusa, ou por desistência. "Eu não sei, a não ser que fizesse um tratamento longo para o álcool, mas ele não quer se tratar. E acho que devia fazer um tratamento espiritual, porque em Ana Rech ${ }^{3}$ ele já se internou e voltou." O segundo aponta para o que se poderia designar como sendo da natureza humana de cada um, ou seja, os atributos pessoais que tornam uma pessoa confiável ou não aos olhos dos outros. "Acho que não, porque o jeito dele é assim, ciumento. Ele já fez outra vez, dei uma segunda chance, e ele não mudou. Na hora falam que vão mudar, mas não cumprem o que prometem." Outra fala segue na mesma direção: "Nunca, nunca. Há uns 18 anos atrás minha mãe me disse: "Esse cara não presta”, eu não dei bola. Hoje vejo que ela tinha razão."

Esses três testemunhos mostram que a descrença reside na desconfiança, ou seja, pura e simplesmente, não acreditam em quem não confiam, porque a experiência mostrou-lhes que os agressores fazem o que está a seu alcance para mantê-las amarradas às mesmas situações opressivas. A descrença se reflete nas mesmas razões, por meio das quais revelam querer libertar-se das relações que mantêm. O último grupo é

\footnotetext{
3 "Ana Rech" é a expressão usada pelos populares para designar uma clínica de repouso e tratamento psiquiátrico localizada nessa mesma comunidade, afastada do centro da cidade de Caxias do Sul, denominada Clínica Dr. Paulo Guedes.
} 
talvez o mais inusitado, e aponta para o plano emocional. Duas situações são referidas: a primeira liga-se à presença de filhos. A separação acontece, mas a reconciliação volta sempre em razão dos filhos. Em vista disso, ela (a mulher) cede, e tudo reinicia. Mas não por crença de que desta vez poderá ser diferente, mas porque é uma teia da qual a vítima não consegue se desenredar. A segunda situação tem a ver com a manifestação de um amor obsessivo. "Acredito que não. Sabe aquele amor desmedido que dá medo? O meu medo é esse, já que ele diz que me ama, mas tá me obrigando a viver com ele." Também o amor é evocado como causa para oprimir.

Como vimos relativamente ao modo de intervir em relação ao agressor, a crença na sua ressocialização está muito dependente da experiência de vitimação que as mulheres estão vivendo. Se a ideia é buscar uma proteção que impeça o agressor de se aproximar delas, a própria intensidade da situação que estão vivendo coíbe qualquer representação positiva em relação à sua eventual ressocialização. Tudo o que a mulher vítima pede é a possibilidade de recomeçar a vida fora do atual quadro de relacionamento. Um recomeçar que as proteja e, às vezes, também aos filhos, da violência que sobre elas é exercida. A crença na capacidade de regeneração do agressor é partilhada apenas quando a violência é mais contida e intermitente ou quando se associa a um relacionamento que talvez seja viável se houver outra forma de neutralizar as manifestações mais críticas por parte do agressor. Acredita-se que o recurso a uma forma de controle externo é suficiente para aplanar essas manifestações. Mas uma coisa é certa: sem uma intervenção protetora, não é possível controlar o agressor; muito menos defender a vítima ou fazê-la sair do círculo da violência.

\section{A DENÚNCIA: UM PEQUENO GRANDE PASSO}

O que significa a denúncia na vida das mulheres vítimas? A análise dos testemunhos mostra que sempre alguma coisa acontece. É um passo em direção a um processo, que, por vezes, pode ser longo. As diferenças de testemunhos têm a ver com as diferenças que se encontram na duração desses processos. Algumas estão ainda no limiar. Não sabem o que virá a seguir e, muito menos, como acabará esse processo aberto pela intenção de denunciar, de pôr fim à violência que as vitima. À pergunta "Depois de contactar o Centro de Referência/Delegacia da mulher, você conseguiu mudar 
a sua posição no que se refere à violência?", uma mulher respondeu: "Acho que não, estou na luta, começando agora." É uma mulher de certa idade, cujos filhos já saíram de casa e, por isso, se sente, hoje, com força para enfrentar a violência do marido que a oprimiu durante anos a fio.

Observa-se, frequentemente, que a violência de gênero é transversal a todas as classes. Também se deveria referir que está presente em qualquer idade, podendo afetar tanto mulheres mais novas como também as que têm mais idade. A decisão de romper com o ciclo de violência não é tarefa fácil, seja qual for a idade da vítima, porque a experiência do medo é comum. Mas o fato de denunciar, de recorrer ao serviço do Centro de Referência ou à Delegacia Especial de Mulheres, é uma esperança, um primeiro passo num processo longo de emancipação.

$\mathrm{O}$ fato de se perceberem como integradas a uma rede de apoio institucional permite-lhes encarar a situação pela qual estão passando, numa perspectiva diferente no sentido de que ganham consciência dos direitos que têm e da intervenção que é possível fazer. O apoio e as orientações que recebem são muito importantes para devolver às vítimas um sentimento de segurança sem o qual se tornaria muito difícil articular uma mudança na situação opressiva que experimentam. Através de encaminhamentos ou ativando o dispositivo policial, as vítimas recebem provas de proteção de que sempre estiveram carentes. Isso não quer dizer que o processo seja linear nem que uma ação, desencadeada com o agressor, signifique o fim da violência. Há casos em que se repete. "Denunciei depois de apanhar. Eles levaram meu marido, e quando ele voltou, continuou sendo violento." A denúncia não estanca automaticamente a violência e, normalmente, aumenta o receio delas em relação à reação do agressor. Mas o fato de a situação ter sido denunciada impede-a de remeter-se uma vez mais ao silêncio, e isso proporciona à vítima, novos meios de defesa e orientação para enfrentar a violência.

Na maior parte dos casos, as medidas de intervenção não são extremas, exceto quando se trata da integridade da vida da vítima ou dos filhos. A proteção passa por colocá-la fora do alcance do agressor, numa casa de apoio, em que vive numa situação protegida e, a partir da qual, procurará reconstituir a sua vida, que implica sempre uma procura por independência econômica. Retrospectivamente, percebeu-se que essas duas condições, ou seja, o afastamento físico do agressor, implicando, não raras vezes, uma 
mudança de cidade e o acesso a um trabalho são, em alguns casos, necessárias para romper de forma definitiva o ciclo de violência, restituindo à mulher o direito de viver sua vida com liberdade. Muitas mulheres reconhecem que a sua situação melhorou logo que conseguiram aumentar a distância física em relação ao agressor. "Sim melhor porque estou aqui [casa de apoio] e estou longe dele." Quando a distância física não está presente, a violência tende a se prolongar, sobretudo através de pressões e ameaças psicológicas, mesmo depois da separação. $O$ fato de não se interpor uma fronteira física, diminui a segurança que pode ser proporcionada à vítima.

Como se mencionou, o fim do ciclo de violência é um processo, por vezes longo, que tem início com a denúncia, porém não quer dizer que não haja antecedentes, mas a intenção de denunciar marca, de forma simbólica, todo o processo. $O$ ato de denunciar reflete, em primeiro lugar, a decisão da vítima de querer pôr termo à violência que a oprime, depois, em segundo, marca a publicização do ato, o assumir a vergonha que, muitas vezes, encobre e impede a denúncia. Por último, há a recusa de viver subjugada no e pelo medo, aprendendo a enfrentá-lo através dos recursos que são mobilizados em sua defesa pela rede de proteção à mulher.

Nos testemunhos das mulheres, todo esse apoio é referido como fundamental e sem o qual não se teria iniciado, na maior parte dos casos, o processo que tem levado um número crescente de mulheres a reencontrar a liberdade que haviam perdido ou que nunca julgaram ser possível de alcançar.

Esses testemunhos são prova da necessidade de uma política pública que torne as relações de gênero mais igualitárias. A violência representa a forma mais básica de impor uma relação de poder, razão pela qual se torna intolerável o seu uso numa sociedade que visa a garantir direitos iguais para todos.

\section{DE PARCEIRO A AGRESSOR: O CÍRCULO DA VIOLÊNCIA}

A agressão eclode num tempo que não tem hora marcada, mas acontece com alguma freqüência, logo no início dos relacionamentos. Como refere uma mulher jovem, vivendo maritalmente há menos de um ano: "Que ele me bateu? [Ele] me bateu desta vez, mas já foi agressivo outras vezes. Começou depois de vivermos [juntos], e ele não tem motivos." Outra mulher mais velha, mas também com um tempo de relacionamento curto, 
inferior a dois anos, aponta o mesmo: "Teve início após seis meses de relacionamento. Ele vai beber nos bares e volta para casa e quebra tudo." Aqui se denuncia também uma das razões que leva a violência a se manifestar. Mas seria errado pensar que a agressão não pode surtir mais tarde, mesmo após muitos anos de relacionamento. Ao fim de um quarto de século, casada com o mesmo homem, uma mulher expressa o seu sentimento de vítima: "Já faz algum tempo que a gente não ta mais se entendendo. Agressão, agressão não é muito, mais é com palavras verbais, humilhação, ele me humilha." Às vezes, a violência demora a eclodir ou porque fica latente durante muito tempo, ou porque espera por circunstâncias da vida que alteram os comportamentos e os relacionamentos.

As pessoas, aparentemente, deixam de ser o que eram e deixam de agir como faziam, embora se possa perguntar se não se acentuaram apenas comportamentos e disposições que, de certo modo, sempre transportaram consigo. Noutros casos, é a vítima que se compadece com a violência e a transporta silenciosamente ao longo de um relacionamento que se vai alongando no tempo: "Há 16 anos já existia violência. Sempre foi controlador e ciumento. Ciúmes, achar que era superior." Também nesse testemunho se vislumbram outras razões para a violência, como se houvesse razões para ela. A elas voltaremos, mais tarde, para aprofundar a questão.

Já era sabido que a denúncia pode permanecer muda e encoberta por longos períodos. Quer-se, agora, fazer notar que a eclosão da violência não tem hora marcada nem moldura relacional certa. Partiu-se do pressuposto de que ocorre dentro de um quadro conjugal, como se esse fosse sempre um invólucro contextualmente delimitado. As texturas relacionais são, por vezes, intermitentes e se prolongam, pelo menos do ponto de vista do agressor, além dos vínculos e das reciprocidades relacionais. É assim que a agressão, a ameaça, aparece mesmo quando os vínculos formais e subjetivos cessam ou deixam de ser recíprocos. "É ex-marido, mas para ele eu continuo sendo mulher dele, mas da minha parte, não." A violência acentua-se, em alguns casos, após a separação. O ciúme, tão presente nos testemunhos, é uma referência ao sentimento de posse, manejado pelo agressor como se de um direito se tratasse para perseguir o outro, então metamorfoseado em vítima. O agressor não está sempre presente através de um vínculo atual, de marido ou companheiro. Também acontece entrar em cena a qualidade de "ex", ex-marido ou ex-companheiro, que denuncia um exercício de violência que ultrapassa as razões circunstanciais e situacionais da vida e rotinas cotidianas. 
Essa síndrome da perseguição pode revelar ou não patologias próprias, mas não pode deixar de ser relacionada com a ideia que os agressores fazem do seu papel enquanto homens, em particular no que se refere ao seu relacionamento com as mulheres no âmbito de um convívio conjugal.

É difícil reconhecer o contrário, e nenhum testemunho o faz: ninguém embarca num relacionamento com violência. Um ou outro caso aponta a comportamentos problemáticos anteriores, mas nada que pudesse ser visto como uma ameaça: "Nós já nos conhecíamos dois anos antes, ele não era violento, ele tinha picos de violência e, nos últimos tempos, piorou." É evidente que o clima emocional tem também responsabilidade na forma como se olha o comportamento do outro: "Ele usa maconha desde os 15 anos de idade. Tivemos rompimentos, onde acabava saindo de casa. Sempre lhe dava chance de voltar, acreditando que ele ia melhorar."

Mas, mesmo denotando a existência de problemas de comportamento, nenhum testemunho registra situações de violência, que passaram a existir depois, às vezes muito depois, como vimos. Noutras situações, a violência se precipita num ápice: "Agora eu casei e você vai fazer o que quero. Até hoje ele é violento, mesmo separado." E não se julgue que é o único caso: “ $A$ agressão começou um ano após estar morando junto, após o nascimento do nosso filho." Outro testemunho corrobora o mesmo: "Após 45 dias vivendo junto, houve a primeira agressão, ameaça verbal contra mim, meu pai, meu irmão." Como entender um registro anterior quase sem referência de violência e uma eclosão tão prematura no limiar do relacionamento?

Poder-se-ia aventar o calor da paixão como uma forma de obstaculizar o conhecimento do parceiro, mas nenhum testemunho o evoca. Razão mais prosaica é a intermitência dos encontros, dos envolvimentos e dos relacionamentos; em uma palavra: as circunstâncias em que se conhece um provável parceiro e o tempo que se demora para tomar a decisão de permanecer ou não com ele. Às vezes, os dois acontecimentos quase se fundem num só: "Um mês antes de morarmos juntos; não conhecia há muito tempo não. Apareceu de repente, era uma pessoa boa, ele não bebia. Sim, já nos conhecíamos desde seis meses antes de morarmos juntos na minha casa."

Noutros casos, o conhecimento pré-conjugal é mais dilatado: "Quando namorávamos (dois anos e meio), ele não apresentava comportamentos violentos." Noutro testemunho já referido, o conhecimento não era também recente: "Nós já nos 
conhecíamos dois anos antes, ele não era violento..." O conhecimento anterior, nesses casos, não parece ser determinante. É claro que é mais fácil dissimular uma predisposição violenta num tempo curto do que num mais longo ou quando a interação é escassa em vez de frequente. Mas o ponto que importa sublinhar consiste no fato de que, do ponto de vista da vítima, nenhum parceiro as amedrontou ou as ameaçou antes do início do relacionamento. É verdade que, nalguns casos, o tempo poderá não ter sido suficiente para que essas manifestações tivessem ocorrido, porém, nos testemunhos, há outras imputações que importa inventariar.

Se a violência não era conhecida antes do relacionamento, como explicá-la? O recenseamento dos motivos apontados pelas mulheres, vítimas de violência, sugere a existência de duas categorias principais: drogas, incluindo o álcool, e violência/dominação. No que respeita à primeira categoria, os testemunhos sugerem a existência de histórias antigas com o consumo de drogas, que terá sido retomado em tempos mais recentes, dando origem a alterações comportamentos e relacionais que surgem associadas a manifestações de violência. "As agressões começaram depois que começou a usar drogas mais pesadas, tipo o crack. Ele era usuário antes de ter ido viver com ele. Ele tinha parado e faz uns dois anos que começou de novo. Bom, o drogado como se diz 'ele nunca tem remédio'." O álcool não surge tão associado a histórias passadas, embora possa aparecer referência ao alcoolismo existente na família do agressor. Seja como for, a associação entre violência e consumo de álcool é muito forte. "Ele bebe na sexta, sábado e domingo. Vai beber nos bares e volta para casa e quebra tudo."

Ora, nenhum desses comportamentos se manifestou antes do início do relacionamento, mesmo quando era conhecida a predisposição anterior ou familiar para esse tipo de consumo. A partir de certa altura, é retomado ou reiniciado com mais intensidade, provocando a eclosão da violência.

$\mathrm{Na}$ segunda categoria, a referência à violência aparece sem qualquer relação ao consumo de substâncias. É por vezes uma violência gratuita, sem motivo. Como refere uma vítima: "Começou [a bater] depois de vivermos juntos, e ele não tem motivos." Essa formulação é um pouco estranha porque parece sugerir que na ideia da vítima poderiam existir motivos que justificariam o uso da violência. Essa observação volta a emergir noutro depoimento: "Mas eu não fiz nada, eu faço tudo direitinho, cuido da casa e não dou 
motivos." Noutros casos, ainda elas dizem: "Fui eu que o provoquei e aí ele ficou nervoso", como se a violência pudesse ter justificação em algumas circunstâncias. Em certas situações, essa violência surge claramente assumida como uma forma de exercer certa dominação. Convocando de novo um testemunho já reproduzido: "Agora eu casei e você vai fazer o que eu quero", outra mulher que refere a existência de violência desde o início do relacionamento, alega que a separação não significou o término da violência. Há, nesses casos, um imperativo de controlar a mulher, de impor uma dominação, que, por vezes, pode parecer doentia. Por ser obstinada, revela ser, no fundo, uma forma de mostrar que o agressor tem poder sobre a mulher, de não aceitar uma relação igualitária.

Essa forma de conceber o papel do homem, como dominante e dominador, tem consequências violentas quando é posta a circular nos interstícios das relações de gênero. A dominação normalmente se apresenta como um jogo de força, uma exteriorização da violência, desde a voz da ameaça até a dor física da agressão. O ciúme a que muitos testemunhos se referem como causa da violência não pode ser desligado desse contexto de dominação. "Por ciúmes! Não podia sair de casa." São sempre suposições imaginárias ("Anda desconfiado que esteja aprontando para ele, ou seja, traindo com outro homem no trabalho"), mas com consequências bem reais. Esse sentido de controle e de domínio não fica apenas reservado à esfera emocional. Também se estende a tudo quanto possa ser entendido como ampliando a margem de liberdade da mulher: "Meu marido começou a ficar agressivo quando resolvi fazer o curso para trabalhar." Outra mulher revela: "Foi quando comecei a trabalhar." Como se a autonomia profissional da mulher pudesse constituir uma ameaça a uma dominação, que se alimenta de dependências, e que, na ausência delas, não pudesse deixar de substitui-las por aquela que surge como a mais irremediável e destrutiva: a do medo. Em outra via, com o trabalho da mulher fora de casa, as representações desse agressor podem estar associadas à falta de exclusividade no exercício das tarefas domésticas e no cuidado dos filhos, requerendo sua participação na partilha das mesmas e não estando disponível em tempo integral para "servi-lo". 


\section{MEDO, VIOLÊNCIA E DOMINAÇÃO: OS (DES)CAMINHOS PARA A SUPERAÇÃO}

É um traço comum aos testemunhos reconhecer que a experiência do medo acompanha suas vidas. Através dele, o agressor domina a vítima, exercendo sobre ela um poder que a sujeita aos seus comandos. O domínio exterioriza-se, como se viu, pelo uso da força física, mas se reproduz através de uma pressão psicológica em que a ameaça ocupa um lugar permanente. O medo a que as vítimas se referem ultrapassa o da coação física para se colocar no plano da integridade física, da própria vida. A ameaça de morte faz parte da dominação psicológica através da qual se procura sujeitar a vítima. A ameaça não se limita à mulher, estendo-se, em alguns casos, a familiares e amigos. A ameaça de morte é levada a sério tanto mais quando, por vezes, são reforçadas com a referência a armas.

À pergunta sobre o receio que tem em relação ao que o agressor possa vir a fazer, uma mulher responde: "Sim, que ele mate minha amiga, já que porta armas." Outra confessa: "Tenho medo das atitudes violentas que o agressor possa ter comigo, com os meus filhos, o meu pai e o meu irmão." Esse medo que parte da ameaça, mesmo que não assuma contornos imediatos, gera consequências práticas, entre as quais se conta a inibição da ação. A liberdade da mulher é afetada, visto que deixa de poder fazer o que pretende fazer, isto é, as suas decisões são coagidas. Uma mulher diz que evita frequentar a escola com receio que isso possa desencadear, no agressor, comportamentos violentos, e outra refere: "Tem medo de retornar para casa com medo de ser agredida novamente."

A perseguição à vítima leva-a, muitas vezes, a abandonar a casa onde vive: "Ele tem ido ao meu trabalho, por causa disso vim para a cidade, para casa de uma amiga." Essa impossibilidade de voltar para casa, sem ter certeza de não precisar encarar o agressor está também bem-expresso nesta fala: "Ele falou que ia trabalhar, mas tenho medo de lá ir buscar minhas coisas hoje, e ele estar escondido. Meu filho também tem medo." Nem sempre os filhos, ao contrário da mulher, são objeto das ameaças. Há casos, certamente raros, em que podem constituir um invólucro de proteção: "Ontem como ele se drogou, tenho medo de ele me pegar na rua sozinha e me agredir, me matar. Porque em casa, na frente dos filhos, ele não vai fazer nada." Outra mulher também é peremptória: "Ele pode me matar. Os filhos, ele não ameaça, o problema é eu." Noutras situações os 
filhos podem ser usados como pretexto para permitir uma aproximação com a vítima: "O maior receio é que ele use o meu filho com mentiras e falsas promessas para conseguir voltar a se relacionar comigo."

A violência é sempre dirigida à mulher mesmo quando não é um alvo exclusivo. É uma relação de poder, de poder absoluto que é exercido pela coação física e psicológica. Mas, sob essa violência, não se encontra apenas a impulsividade incontrolável de um "mau gênio" masculino ou os desvarios comportamentais provocados pelo excesso de álcool ou o consumo de drogas; por detrás dos atos e das palavras em que a violência se translada, radica a ideia de que a mulher pertence ao homem e que deve se sujeitar à sua vontade: "Sim, porque ele diz que se eu não for dele, não serei de mais ninguém, porque ele vai matar meu pai e meu irmão, porque ele não gosta deles. Ele tem um revólver 38 e não tem porte de arma." Ou na expressão de outra mulher: " $A$ agressão, dele no caso, é por eu não querer mais ele." Essa ameaça traduz um sentimento de posse, de que a única vontade que conta é a do homem, não restando à mulher outra alternativa que a sujeição.

A violência torna-se, portanto, o meio de consubstanciar uma relação de poder, que encontra a sua justificação numa cultura de masculinidade, que advoga a superioridade masculina em relação à feminina. Aliás, essa cultura não se manifesta apenas no recurso à violência, mas também está presente noutros comportamentos já referenciados, designadamente, o consumo de álcool e de drogas. Com efeito, há uma associação entre a aquisição desses vícios e a afirmação viril da masculinidade. $O$ ato de beber, por exemplo, é transmitido aos jovens como sendo um comportamento masculino, como uma forma de se afirmarem como homens e, por isso, os excessos são tolerados na medida em que não deixam de ser expressões, certamente por excesso, da masculinidade. $O$ mesmo comportamento numa mulher seria, sem dúvida, impensável e alvo de uma censura radical que macularia, irremediavelmente, a sua reputação aos olhos dos outros.

Seja como for, o ponto que se gostaria de deixar assinalado é que não é possível desligar a violência da construção da masculinidade ou, pelo menos, e de certa forma, de entendê-la.

Regressando aos testemunhos das mulheres, é possível entender melhor a experiência do medo, se for considerado que o agressor é visto, agora, numa perspectiva muito diferente da que elas tinham, no início do relacionamento. Conforme referido, 
nenhuma mulher assumiu, pelo menos de maneira explícita, que o parceiro com quem iniciou um relacionamento tivesse manifestado irrupções ou impulsividades agressivas e violentas. Tudo, dizem elas, começou depois, às vezes logo depois de terem começado a viver juntos; outras revelam que foi depois do nascimento do primeiro filho; outras ainda muito mais tarde, ao cabo de muitos anos de vivência conjunta. Após a eclosão da violência, todas mudam a perspectiva com que olham o parceiro. Nele, passa a existir um agressor, alguém que atenta contra a integridade física e psicológica. $O$ parceiro, antes considerado não violento, passa a ser descrito como violento. Uma violência que encobre, bem-entendido, várias intensidades, que pode ser direcionadas exclusivamente contra a mulher ou ter ainda outros alvos derivados.

Mas é importante que se note que a violência raramente é esporádica. Apenas uma mulher assinalou que a manifestação de violência era rara. A violência tende a ser repetitiva e intensa. A maior parte das mulheres sublinha o caráter frequente (muitas vezes) das manifestações agressivas, ainda que exista um número não negligenciável de testemunhos a assinalar uma incidência mais moderada (algumas vezes). Obviamente, a intensidade da violência pode variar em função da histórica de vitimação de cada mulher ou das características do agressor. Seja como for, a violência não tende a desaparecer e nunca é constituída por um único ato.

Outra característica da violência, além da intensidade, é a sua direcionalidade. A mulher constitui o alvo central, a pesar de existirem outros. Aliás, já foram referidos alguns deles anteriormente, designadamente, os filhos. Com efeito, apesar de serem por vezes poupados às agressões e poderem servir, num ou noutro caso, de invólucro protetor da mãe, em inúmeras situações, são abrangidos no raio de ação da violência, quer em termos físicos, quer em termos psicológicos. Outros familiares próximos são também incluídos, pelo menos no campo da agressão verbal. Familiares da vítima, como pais e irmãos, bem como pessoas que mantêm um laço privilegiado com a vítima, por exemplo, uma amiga, são alvos de possíveis agressões. Também familiares do agressor, como a mãe, mulheres com quem teve relacionamentos anteriores ou outras pessoas conhecidas, como vizinhos, são referidos como tendo sido objeto de alguma forma de violência. Bementendido: apenas uma parte dos agressores revela uma gama tão variada de vítimas.

Muitos dos testemunhos apenas referem violência contra a mulher. Mas eles revelam que a escala da violência tende a alargar o raio de ação ao mesmo tempo em 
que se intensifica. Os testemunhos não nos permitem descortinar o processo pelo qual o ciclo de violência se desenvolve e se estende para além do reduto conjugal. Seja como for, não deixam dúvidas de que a violência se instalou no cotidiano das mulheres sobre as quais é exercida.

\section{CONSIDERAÇÕES FINAIS}

Com este texto pretendemos expressar um ponto de vista: o das mulheres que denunciam a violência de que são alvo a partir de uma situação de denúncia. Já não se está diante de uma violência silenciosa, que permanece circunscrita na esfera íntima, posto que, às vezes, o círculo se alargue até a família e, mais raramente, aos vizinhos. Essa "oficialização" da violência marca uma mudança na situação das mulheres que são vítimas dessa violência ao mesmo tempo em que contribui decididamente para acabar com a ideia da "naturalização" da mesma. Sem as políticas de apoio às mulheres, dificilmente, muitas delas teriam condições de denunciar e seria, certamente, mais árduo combater os preconceitos e as construções culturais que tendem a inferiorizar a mulher $\mathrm{e}$ a legitimar a violência.

A denúncia protege a vítima não apenas do sofrimento, mas também da vergonha, outra forma de perseguir a mulher. A criminalização da violência representa a ruptura necessária em relação às interpretações e justificações culturais que, de algum modo, pretendem legitimar.

Apesar de mudança nos quadros social e legal, a violência de gênero continua a perseguir o cotidiano de muitas mulheres, articulando outras vulnerabilidades sociais e econômicas e se alicerçando nas desigualdades das relações de gênero. São essas relações que, em definitivo, encerram a mulher numa malha de dependências que marca o seu processo de vítima e que condicionam grandemente a sua forma de olhar a violência. É desse olhar que procuramos dar conta a partir das narrativas das vítimas, das suas falas sobre a violência, que contra elas é exercida.

A mulher denuncia a violência emocional que se instalou no seu corpo e que acompanha e marca o seu cotidiano. É para fugir das ameaças, da agressão verbal ou física, que denuncia. É, essencialmente, por não mais suportar as atitudes de humilhação, coação e chantagem, que a mulher resolveu dar voz ao seu sofrimento. A mulher 
denuncia por ter medo, por sofrer. Também denuncia por não mais ter "vergonha" de ser vítima, por saber que tem direito a denunciar e por poder contar com o apoio das políticas públicas. É para buscar auxílio que a mulher denuncia. A procura de apoio mostra que a vitimização é uma experiência de medo, de insegurança e de ameaça à sua vida.

A mulher quer proteção, mas também intervenção. Não quer mais ser vítima, quer sua vida de volta de novo. Exige, por isso, que sejam tomadas medidas em relação ao agressor. São necessárias medidas de intermediação, que exerçam pressão legal sobre o agressor, ou medidas repressivas, que impeçam a aproximação do agressor à vítima. Sem elas, o ciclo de violência não se quebra, e tudo reinicia mais cedo ou mais tarde. A política pública não pode atuar apenas no sentido do apoio e da proteção da vítima, necessita também atuar sobre o agressor.

A mulher, igualmente, clama por justiça, pela reparação do dano, pelo fim de seu sofrimento. Nada pode justificar a violência a que são submetidas muitas mulheres. A vítima tem o direito de ser reconhecida nessa qualidade, e o agressor, na de argüido, em razão dos crimes que cometeu. Não se trata de retaliar, todavia de reconhecer que a violência de gênero é incompatível com a dignidade e com o valor da pessoa humana. Os direitos humanos das mulheres têm de ser reconhecidos e, sobretudo, respeitados e cumpridos.

Obstáculos a esse reconhecimento continuam a existir. A "naturalização da violência do cotidiano" é uma das ideias que necessita ser desconstruída, na medida em que permite encobrir muitas situações de discriminação e opressão de gênero. Muitas das representações de violência apenas enfatizam a violência doméstica, sob a forma de agressões verbais e físicas, deixando na invisibilidade outras de suas dimensões, como a sexual, a psicológica e a patrimonial, que resultam das dependências e sujeições tecidas a partir das desigualdades de gênero. A naturalização dessas desigualdades tem permitido cristalizar a subalternidade da mulher em relação ao homem e impedido o reconhecimento da dominação que sobre ela é, de fato, exercida. Os direitos das mulheres reivindicam outra ordem de gênero, que não se baseie apenas na desigualdade e no exercício de relações de dominação, mas numa ordem que pressupõe a igualdade como um elemento endógeno das relações entre homens e mulheres.

Outro aspecto a ser mencionado, refere-se ao lugar dessa mulher enquanto vítima da violência de gênero e que é permanentemente tencionado, sofrendo deslocamentos. 
Desfazer imagens e (re)construir identidades remete à compreensão de que as identidades são múltiplas e não se constituem em torno de um "eu" coerente. Para Hall (2000; 2003) as identidades não são nunca unificadas, pelo contrário, na modernidade tardia, elas são cada vez mais fragmentadas e constituídas através das narrativas. Ao narrarem as suas experiências, em torno da violência de gênero, as mulheres vítimas passam a protagonizar o que Dubar (2006) denominou de a "crise das identidades". Elas se dão conta da situação vivida, procuram ajuda e passam a ocupar um outro patamar no seu processo de individuação, compondo uma outra relação, mesmo que inicial, nos seus trânsitos pelo círculo da violência contra a mulher.

A política pública e a rede informal de comunicação que essas mulheres têm acesso configuram a ponte entre uma ordem e outra, entre a opressão e a afirmação dos direitos. Partindo da vitimação procura criar condições para o empoderamento da mulher, emancipando-a das imagens que a fecham numa condição subalterna e permitindo a reconstituição da sua identidade fora das amarras da violência de gênero. 


\section{REFERÊNCIAS}

ALMEIDA, Suely Souza. Essa violência mal-dita. In: ALMEIDA, Suely Souza (Org.). Essa violência mal-dita: violência de gênero e políticas públicas. Rio de Janeiro: Ed. da UFRJ, 2007.

CHARTIER, Roger. A historia cultural: entre práticas e representações. Tradução-Maria Manuela Galhardo. 2.ed. Lisboa: Difusão Editorial S.A., 1988.

, Roger. El mundo como representación: estudios sobre historia cultural.

Tradución: Claudia Ferrari. Gedisa editorial, 1991.

COELHO, Carolina Marra Simões; GAETANI, Rebeca Rohlfs Barbosa. Metodologias de trabalho em grupos no enfrentamento à violência contra a mulher. In: SEMINÁRIO INTERNACIONAL FAZENDO GÊNERO, 7., e SIMPÓSIO TEMÁTICO 5 - VIOLÊNCIA E GÊNERO. 2006, Florianópolis. Anais... Florianópolis: UFSC, 2006.

CONRADO, Mônica Prates. A fala dos envolvidos sob a ótica da lei: um balanço da violência a partir da narrativa de vítimas e indiciados em uma delegacia da mulher. São Paulo: Edusp, 2001.

DUBAR, Claude. A crise das identidades: a interpretação de uma mutação. Porto: Afrontamento, 2006.

HALL, Stuart. Quem precisa de identidade. In: SILVA, Tomas Tadeu da (Org.). Identidade e diferença: a perspectiva dos estudos culturais. Petrópolis: Vozes, 2000.

A identidade cultural na pós-modernidade. Rio de Janeiro: DP\&A, 2003.

OLIVERIA, Rosiska Darcy. Prefácio. In: SOARES, Bárbara Musumeci. Mulheres invisíveis: violência conjugal e novas políticas de segurança. Rio de Janeiro: Civilização Brasileira, 1999.

PESAVENTO, Sandra Jatahy. História \& História Cultural. Belo Horizonte: Autêntica, 2008.

SOARES, Bárbara Musumeci. Mulheres invisíveis: violência conjugal e novas políticas de segurança. Rio de Janeiro: Civilização Brasileira, 1999.

Enfrentando a violência contra a mulher. Brasília: Secretaria Especial de Políticas para as Mulheres, 2005.

VIEIRA, Danúbia Rocha; PALAVEZZINI, Juliana. Um novo olhar sobre a violência contra a mulher. In: SEMINÁRIO INTERNACIONAL FAZENDO GÊNERO, 7., e SIMPÓSIO TEMÁTICO 5 - VIOLÊNCIA E GÊNERO. 2006, Florianópolis. Anais... Florianópolis, UFSC, 2006.

Artigo:

Recebido em: 28/04/2009

Aceito em: 03/06/2009 